\title{
How Sustainability Is Defined: An Analysis of 100 Theoretical Approximations
}

\author{
Arturo Luque González ${ }^{1,2, *(\mathbb{D}}$, Jesús Ángel Coronado Martín ${ }^{3}{ }^{(1)}$, Ana Cecilia Vaca-Tapia ${ }^{4}$ and Francklin Rivas ${ }^{5}$ \\ 1 Facultad de Ciencias Humanísticas y Sociales, Universidad Técnica de Manabí, \\ Ave. José María Urbina and Che Guevara, Portoviejo 130105, Ecuador \\ 2 Escuela de Administración-Grupo de Investigación en Dirección y Gerencia, Universidad del Rosario, \\ Calle 12C, 6-25, Bogotá 111711, Colombia \\ 3 Facultad de Educación, Ciencia y Tecnología, Universidad Técnica del Norte, Av. 17 de julio 5-21 y Gral, \\ José María Cordova, Ibarra 100105, Ecuador; jcoronado@utn.edu.ec \\ 4 Facultad de Derecho y Ciencias Sociales, Universidad UTE, Rumipamba y Bourgeois, Quito 170147, Ecuador; \\ ana.c.vaca.tapia@gmail.com \\ 5 Departamento de Informática, Universidad Técnica Federico Santa María, Av. España 1680, \\ Valparaíso 2340000, Chile; firivas@inf.utfsm.cl \\ * Correspondence: arturo.luque@utm.edu.ec
}

\section{check for}

updates

Citation: Luque González, A.; Coronado Martín, J.Á.; Vaca-Tapia, A.C.; Rivas, F. How Sustainability Is Defined: An Analysis of 100 Theoretical Approximations. Mathematics 2021, 9, 1308 https://doi.org/10.3390/ math9111308

Academic Editors: Cristina Raluca Gh. Popescu and

Aleksandr Rakhmangulov

Received: 1 April 2021

Accepted: 3 June 2021

Published: 7 June 2021

Publisher's Note: MDPI stays neutral with regard to jurisdictional claims in published maps and institutional affiliations.

Copyright: (c) 2021 by the authors. Licensee MDPI, Basel, Switzerland. This article is an open access article distributed under the terms and conditions of the Creative Commons Attribution (CC BY) license (https:/ / creativecommons.org/licenses/by/ $4.0 /)$.

\begin{abstract}
Sustainability processes are imperfect, hence there is a need to analyze their construction, evolution and deployment. To this end, a sample of one hundred sustainability constructs was taken, together with their conceptual approaches, in order to gauge their impact and to ascertain the dimensions to which they belong. A frequency count and categorization were carried out using Google, which saturated in seven dimensions: economic, social, environmental, legal, political, ethical and cultural. A higher-order association of these hierarchies was then proposed, establishing a triad model that indicated only the most representative combinations of dimensions resulting from the extraction of the most significant definitions. From these definitions and in accordance with their frequency of use in Google, it is inferred that the current concept of sustainability is based on the economic-social-ethical category. This highlights the distance between what, a priori, seems to implicitly allow any definition of sustainability and the existing reality.
\end{abstract}

Keywords: sustainability; google; common benefit; ecological factors; ethics

\section{Introduction}

This study takes a theoretical and problem-solving approach to the processes of sustainability from an empirical, axiological and propositional point of view through an analysis of the definitions of sustainability. To this end, the conceptual deployment and derived impact of these definitions was studied, including the inherent contradictions and connections arising from their theoretical construction (see Appendix A). Although the exact terminology varies from region to region [1], sustainability has the same underlying significance in all ambits. Today, ecological and social concerns are becoming increasingly important as everyday practices are increasingly regarded as unsustainable [2-5], leading to the emphasis on sustainability as the most effective alternative to the dominant developmental model. This model has been especially questioned and criticized for its role in the global ecological crisis and in the increase in global social inequalities. Common welfare must be achieved in a fair and lasting way through a model of use and management of the environment that recognizes that natural resources are limited and finite [6].

The concept of sustainability can be divided into two parts: regulatory sustainability and positive sustainability. The first consists of the agreements and proposals that were the result of the conceptual framework for sustainable development developed by the United Nations (UN), and the second refers to the scientific analysis of sustainability and sustainable development with an economic and ecological bias [7]. 
In 1987, the World Commission on Environment and Development (WCED) made public the Brundtland report, better known as "Our Common Future", which specifies that "Humanity has the ability to make development sustainable to ensure that it meets the needs of the present without compromising the ability of future generations to meet their own needs" (p. 23) [8]. From this moment on, the UN made sustainability the principle that governs global development, while, at the same time, academic debate was opened up to a review of the definitions of sustainability by authors, such as Pezzey or Pearce [1].

The concept of sustainability is very broad and varied, depending on the approach used by authors. In a report to the Economic Commission for Latin America (ECLAC) [9], Gallopín characterizes sustainability as an attribute of systems open to interactions with their external world that lack a fixed state of constancy, tending rather toward a dynamic preservation of the essential identity of the system amid continual changes. Salas-Zapata, Ríos-Osorio and Del Castillo [10] describe sustainability as a science by defining it as "the scientific activity that develops around the study of the ability of certain systems to adaptively adjust their socio-ecological relationships to overcome disturbances and maintain some essential attributes and processes". Moreover, the science of sustainability "involves a way of conducting science in a participatory and transdisciplinary way, accepting the uncertainty inherent in real-world phenomena and, consequently, it is more exploratory and comprehensive than predictive in character" (p. 110).

Sustainability can be defined within the limits of the two typologies of weak and strong sustainability $[1,7,11]$. The first assumes that natural capital and economic capital are fully interchangeable substitutes over a period of time, and the second is based on the economic principle that it is impossible to replace natural resources that pertain to complex natural systems and that, from an economic perspective, are not considered part of the equation. Certainly, in the constitutions of almost all Latin American countries, the development and deployment of sustainability continues to grow despite continuous and systematic environmental degradation and the expulsion and annihilation of cultures [12].

To date, the concept of sustainability remains ambiguous and appears scattered and blurred in the literature [9]. Many of the definitions of sustainability are somewhat abstract and others are decidedly utopian and unquantifiable, hence the objective of this work, which is to analyze these definitions taking into account their cross-disciplinary and dynamic character. From the thorough analysis of academic texts produced by researchers and experts in sustainability processes, 100 theoretical approximations were identified, as set out in Appendix A. Subsequently, a frequency count was carried out using Google, together with a double categorization, in order to discover which dimensions (from the 7 identified) predominate in sustainability processes [13]. From this, a theoretical concept of sustainability was constructed that is a reliable reflection of the current situation, contextualized within the analysis framework used and its intrinsic weaknesses. The Google search was instrumental in ascertaining the real impact of each definition, and it allowed this complex phenomenon to be broken down for analysis. Finally, the necessary factors that contribute to generating sustainability processes were analyzed, together with their institutionalization and regulatory construction. The outcome of the study clarifies whether sustainability processes, by introducing implicit aspects of equality, governance and responsibility, are fully developed in their definitions, or whether the exclusion of certain necessary elements makes them a contradiction of what they claim to be.

\section{Theoretical Framework}

The National Environmental Policy Act [14] committed the United States to sustainability, declaring it a national policy "to create and maintain conditions under which humans and nature can exist in productive harmony, that permit fulfilling the social, economic and other requirements of present and future generations". While it is true that, at the global level, production and pollution have continued at an unprecedented rate and the instances of ecosocial aggressions are unabated, there is no doubt that this statement of intent was a major step toward addressing many of the global problems that are en- 
dogenously created by a model of living based on vanity and continuous consumption. Through this sometimes-involuntary way of life, a large part of the global population is excluded, making them mere subordinates of the developed countries. Sustainability processes are an effective solution to the constant aggressions perpetrated by enterprises, other organizations and individuals on Earth; for example, according to United Nations [15], "today, food losses globally are estimated at $13.8 \%$, equivalent to about \$ 400 million." It should be remembered that populations are ecodependent and interdependent and that it follows inexorably that work must be done to achieve zero loss of waste products and, at the exogenous level, allow readjustment through local, national and supranational public policies. For this to happen, lifestyles must be altered in order to minimize (See www.zerowastehome.com and www.trashisfortossers.com, accessed on 1 April 2021) the amount of waste generated and to contribute to the sustainability and conservation of the environment. This requires the development and implementation of the three key concepts of reducing, reusing and recycling [16]. Among the clear possibilities for achieving this are the inclusion of the water footprint (Water use indicator that takes into account both direct and indirect use by a consumer or producer) and environmental footprint (Biophysical sustainability indicator integrating all of the impacts that a human community has on its environment) in any development initiative, thereby bringing to bear fiscal pressure, as well as marshalling public policies; in other words, the greater the corporate and citizen responsibility, the greater the benefits for all. For example, proposals put forward by Indigenous peoples within the Plurinational State of Bolivia are currently gaining strength. The Plurinational Legislative Assembly defines integral development as the continuous process of generating and implementing social, community and citizen measures and actions, and public overseeing, for the creation, provision and strengthening of material, social and spiritual conditions, capacities and media, within the framework of culturally suitable and appropriate practices and actions, which promote relations of solidarity, support and mutual cooperation, and which are complementary and strengthen community and collective ties to achieve Welfare in harmony with Mother Earth [17].

Consumerism has implicitly achieved part of its objectives, that is, to associate the creation of goods and services with the concept of modernity. This movement-despite being a category that refers to the social and historical processes that have their origins in Europe and have been emerging since the Renaissance- - has been democratized and trivialized. Today it is becoming more ephemeral and personalized than ever, despite its devastating ecosocial consequences, by proposing that individuals set their goals at will, while the prevailing economic system deploys its influence by characterizing its products and services as both attainable and necessary [18]. Moreover, not all processes are sustainable, nor can many ever become sustainable: the electrification of the economy, for example, does not per se imply sustainability $[19,20]$.

\section{Analysis and Discussion}

\subsection{Delimitation of the Dimensions of Sustainability Processes}

The selection and classification of the specified dimensions were designed to reflect the depth, deployment and interconnections observed in the object of study as well as the endogenous characteristics of the concept itself. There are multiple typologies within sustainability processes due to the emergence of new ways of living and producing, as well as the rights associated with these (as claimed by a large part of the public), which are becoming something similar to a social function. The most important consideration was the grouping of related concepts into the seven dimensions: economic, legal, political, social, cultural, ethical and environmental, as set out in Table $1[13,21,22]$. Below is an explanation of the conceptualization of each of these dimensions. 
Table 1. Dimensions.

\begin{tabular}{|c|c|c|}
\hline Dimension & Codification of the Definition & Example of the Search String \\
\hline Economic & $\begin{array}{l}\text { Economic or financial aspects affecting and promoting } \\
\text { sustainability processes }\end{array}$ & $\begin{array}{l}\text { 'new models of economic sustainability' 'speculation' } \\
\text { 'maximization of profit' } \\
\text { 'disruptive processes' 'social economy' }\end{array}$ \\
\hline Legal & $\begin{array}{l}\text { Regulations, attitudes and ideologies that produce } \\
\text { certainty and contribute to the development of } \\
\text { biological systems that remain productive over time }\end{array}$ & $\begin{array}{c}\text { 'increase in the powers of bodies responsible for } \\
\text { prevention/monitoring/sanctioning to halt } \\
\text { regulatory abuse' }\end{array}$ \\
\hline Political & $\begin{array}{l}\text { Areas that are concerned with power relations, } \\
\text { political leadership behaviors, public opinion, } \\
\text { international relations and armed conflicts }\end{array}$ & $\begin{array}{l}\text { 'promoting equal rights in order to live in an area or } \\
\text { neighborhood in a non-invasive way' 'national and } \\
\text { transnational regulation' }\end{array}$ \\
\hline Social & $\begin{array}{l}\text { Aspects that determine and characterize the quality of } \\
\text { life of the inhabitants of a given area }\end{array}$ & $\begin{array}{l}\text { 'protection according to needs: equity' 'social } \\
\text { inclusion' 'protection of a healthy and dignified life } \\
\text { (welfare) above other purely economic elements' } \\
\text { 'management of unlimited consumption on a } \\
\text { finite planet' }\end{array}$ \\
\hline Cultural & $\begin{array}{c}\text { System of values, beliefs and ways of establishing a } \\
\text { society as a mental construct based on } \\
\text { geographical identity }\end{array}$ & $\begin{array}{l}\text { 'conservation of popular traditions' 'identity' } \\
\text { 'cultural heritage' }\end{array}$ \\
\hline Ethical & $\begin{array}{l}\text { That which shapes man's moral principles and virtues } \\
\text { in regard to their responsibility for their actions, to the } \\
\text { projection to the community, and to the construction of } \\
\text { a healthy coexistence }\end{array}$ & $\begin{array}{l}\text { 'values' 'set of norms and customs that direct or value } \\
\text { human behavior in a community' 'citizen awareness' } \\
\text { 'promotion of social ethics' 'primacy of the person: } \\
\text { how we ought to live' 'processes of } \\
\text { social responsibility' }\end{array}$ \\
\hline Environmental & $\begin{array}{l}\text { Natural or altered system in which humanity lives, } \\
\text { with all associated social and biophysical aspects and } \\
\text { the relationships between them }\end{array}$ & $\begin{array}{l}\text { 'pollution' 'reduce, reuse, recycle' 'significant } \\
\text { alteration of natural and transformed systems and } \\
\text { their resources, caused by human actions' } \\
\text { 'contribution to the protection and maintenance } \\
\text { of biodiversity' }\end{array}$ \\
\hline
\end{tabular}

The economic dimension, despite including a broad social component, suffers from dysfunctions, such as high levels of public and private debt; risks, such as inequality, whereby growth does not often reach the people who need it most; and the deployment and standardization of processes of financial speculation. These risks should be minimized in order to achieve a dignified, fulfilling and harmonious life. There are dangers such as (1) increased trade disputes, (2) stress in financial markets, (3) rising geopolitical tensions, (4) market volatility (in many cases due to financial speculation) and (5) monetary policy adjustment. Hence, there is a need to be aware of changes in the methods of production and their relationship with the environment at all levels by establishing new parameters for production as well as by providing support for public administrations. The social economy attempts to correct many of these dysfunctions, drawing strength from values such as mutual aid, responsibility, democratic values, processes of equality, equity and solidarity, all of which can be supported by binding legal elements [23]. According to Rostow [24] what the economy demands, the law must provide, and the work of the economist is becoming exclusively political through the means provided by legislation, hence the need to establish instruments of verification in order to be able to analyze and redress the harm caused by certain measures that, while legal, may be immoral [25]. According to Leguizamón it will be the responsibility of economic law, because of its great resources and its enormous regulatory power that transcends all fields of social activities, to play a role of the greatest importance in obtaining the objectives of its fundamental principles, which are in perfect interaction with the development of environmental policies (p. 339) [26].

The legal dimension pivots around its relation to the development and deployment of regulations that, in line with the existing historical, social and political circumstances, is legally valid for a given population and thus guarantees the general interest. It is based on 
the formation of public policies that have the capacity to generate, endogenously, greater ethical, social and responsible practices and behaviors. The establishment of sustainability can be interfered with by such processes as liberalization, deregulation, regulatory hybridization, the formation of lobbies, economic and fiscal reforms, free trade and investment treaties, private arbitration courts and processes that exert legislative pressure [27].

Thirdly, the political dimension consists in the response of civil society and its organization through trade unions, associations, communities, neighborhoods and political parties, among others. One of the tools available to society is civil disobedience as a democratic instrument and, indeed, violence, which must be deconstructed to be analyzed as a response to conditions of despair and constant asymmetries, such as the production of pollution and political and social regulation that favors the minority that holds power and controls capital.

The social dimension is concerned with the cohesion and stability of the population. It relates to the impact of an organization's activities on the social systems in which it operates, including decent employment, human rights, health and social security, public services, population displacement, education and the formation of society based on criteria of public welfare. This also extends to the acceptance of responsibility for the goods and services offered that affect society as a whole, in particular those aspects that determine and characterize the quality of life of local populations at the national level, or through supranational interventions in which the state has the responsibility and capacity to improve the conditions of different social groups [28].

The cultural dimension comprises the need to take an integrated view of development, in which culture is recognized as the multidisciplinary and dynamizing axis of social participation. It accommodates all of the distinctive features that characterize a society or a given social group, including traditions and spiritual, material, intellectual and affective aspects. It also encompasses the arts and literature, ways of life, fundamental human rights, and systems of values and beliefs that have many interrelated meanings [29]. Expressions of the cultural dimension are grouped implicitly and distinguished from others by their reference to humanity.

The ethical dimension includes the fundamental question of how we should we live. Consequently, there is a clear need to direct societies toward rational growth within the natural boundaries set by the Earth. The continuous and systematic deterioration of the environment, the loss of biodiversity, soil degradation and the pollution of surface and groundwater resources represent the continual harm done to all types of ecosystems in favor of the maximization of capital. This has inevitably triggered problems, such as negative climate change, that are often beyond redress and repair.

The environmental dimension highlights the lack of harmonious development between growth and its relationship with the environment since the current developmental model, based in its entirety on the infinite expansion of goods and services, is in conflict with the finite limits of the Earth [30]. It should be noted that the planet is facing a triple environmental emergency of climate change, pollution and loss of biodiversity, hence the need to incorporate the concept of climate neutrality as a strategy in all coordinated actions between stakeholders. It is necessary to incorporate verifiable mechanisms for addressing environmental issues and to provide sufficient resources and tools for their effective deployment. Mechanisms include elements designed to redress, sanction and prevent regulatory abuses, such as those free trade agreements that prioritize the economic over the environmental interest and thereby maintain the existing hegemonic logic that economic growth is facilitated by the abuse of the external physical, chemical and biological components with which living beings interact [31]. The risks to which the Earth is exposed are manifest since the global community has failed to meet its commitments to limit environmental damage by reducing greenhouse gas emissions or putting in place carbon offsets. It is necessary to replace the existing extractivist and anthropocentric vision by promoting the establishment of shared interests that protect all forms of life over private interests dominated by capital. The commodification of nature must be called into question 
and much of its operating rules redrafted, having been imposed by a global society interconnected directly with the spending capacity of each individual. This phenomenon has been hitherto supported by (un)sustainable companies, governments and supranational organizations. Socioenvironmental tools must be established to break the dynamics of concentration and exclusion based on a clear understanding that the material basis of all human activity is found in nature and the assumption that ecosystems and natural resources have certain limits. Due to their inherent sustainability, environmental issues inexorably have an impact on the work of safeguarding life; therefore, the environmental dimension must be incorporated as a vehicle for development that promotes the future of the entire world population and its quality of life.

\subsection{Compilation of Definitions of Sustainability}

Sustainability processes have been widely studied and are not limited to one type nor are they linear in nature. Hence, there is a need to begin the experimental procedure with the search for concepts, academic constructs and related elements with the aim of being able to analyze their implications, connections to other fields and constitutive components. This search was based on the academic literature (i.e., research) but also included primary information derived from companies and other organizations, nonacademic experts and other institutional sources. From this starting point, Google Scholar was used to perform Boolean searches of keywords or phrases, such as those in Table 1, which form the basis of the mathematical sets and the logic needed for database searches. Basic operators such as AND, OR and NOT connect the words entered into the search engine to narrow or extend results.

The pre-established definition of the search chains, concomitant to the literature review, saturated in seven categories of sustainability. The process was carried out between 16 November 2020 and 11 February 2021 and resulted in the compilation of 100 units of analysis (UA) (Appendix A), a sample that, according to similar studies, is of sufficient size for a qualitative study (The number of times a particular citation is published is conditioned by the period in which that frequency of occurrence is measured. We assumed that the absolute frequencies thus obtained can only grow or remain stationary temporarily while others increase, resulting in a decrease in the relative frequency. The validity of the analysis is subject to the period in which it is determined to measure how much a certain construct is represented, if at all. Far from being an impediment, we think that interest in the dynamics of sustainability processes lies precisely in this point) [13]. After the Google frequency count of the number of times each of the 100 definitions was cited or referenced, they were assigned dimensions according to the pre-established system of encoding, and the corresponding absolute frequencies, $f_{i}$, were obtained as shown in Appendix A. This stage involved several outline conditions for UAs, namely (1) that at least one academic reference be required, (2) that it not be duplicated in different databases and (3) that it may appear in one or more categories, up to a maximum of seven.

\subsection{The Study of Dimensions}

Once the qualitative approach of this research had been developed, the next step was to explore the scope of each category, as well as its contribution to sustainability processes. The 100 UAs were assigned dimensions within one or more categories, up to a maximum of seven, and the number of times that concept of sustainability had been used in a given time period of approximately 4 months was counted $\left(f_{i}\right)$. In addition, the existence of the seven dimensions unfolds the absolute frequencies in the corresponding $f_{k j}$, or, to express it another way, the $f_{i}$ of a unit of analysis $k$, associated with a category $j$. Thus, it was possible to obtain the relative weighting of each $j$ dimension according to Equations (1) and (2), respectively, $(j=1, \ldots, 7)$ :

$$
C D_{j}=\sum_{k=1}^{y} f_{k j}
$$


where $C D_{j}$ is the scope of each $j$ dimension, and $f_{k j}$ is the frequency of occurrence in Google of each unit of analysis $k$ associated with a $j$ dimension.

$$
\% P D_{j}=\frac{C D_{j}}{\sum_{i=1}^{x} f_{i}} 100
$$

where $P D_{j}$ is the relative weighting of each $j$ dimension, expressed as a percentage $(\%)$, and $f_{i}$ is the absolute frequency of occurrence in Google of each UA or bibliographic reference $k$ in a given period of time.

The values obtained from Equations (1) and (2) are given in Table 2. The rating of the social dimension $C D_{3}$ corresponds to the sum of all $f_{k j}$ up to the total of $y$ concepts categorized within it. Its contribution to the study is calculated as the relationship between this value and the summation of all absolute frequencies $\left(\% P D_{j}\right)$. It follows that the ethical dimension contributes most to sustainability processes, with a factor of 0.69 , while the legal and cultural categories are the least representative with a factor of 0.06 and 0.09 , respectively.

Table 2. Scope dimension.

\begin{tabular}{lccc}
\hline$j$ & Dimensions & $\boldsymbol{C D}_{\boldsymbol{i}}$ & $\boldsymbol{\%} \boldsymbol{P \boldsymbol { D } _ { \boldsymbol { i } }}$ \\
\hline 1 & Economic & 8988 & 31 \\
2 & Legal & 985 & 3 \\
3 & Political & 7599 & 26 \\
4 & Social & 20,975 & 72 \\
5 & Cultural & 1291 & 4 \\
6 & Ethical & 23,378 & 80 \\
7 & Environmental & 7349 & 25 \\
\hline
\end{tabular}

It should be noted that the rating obtained for each dimension and its relative weighting are directly proportionate, and it should be specified that each $C D_{j}$ is determined by the use of a citation $k$ by a user, presuming that its use depends on the independent variable of time (set for the seven categories). The contrast is striking between the ethical dimension, found in $80 \%$ of definitions, and the legal dimension, which accounts for around one-eleventh of the total. This was a result of using two large sets of variables- $C D_{j}$ and dimensions - and the fact that, to facilitate the study, the established dimensions were kept constant. However, the rating assigned to each of them might vary, even in those from the same author (Dispersion in the category allocation process was resolved by an iterative technique until the degree of disagreement was below 15\% (three steps)). To minimize the impact of qualitative research on data processing, categorization consisted of a three-stage iterative process that included the concept but not the author(s). Given the large volume of definitions used here, this procedure ensured accuracy in the $C D_{j}$ more reliably than that which would have assigned, in a single stage, a high value to each $C D_{j}$ (thereby jointly increasing relative weightings), as other authors in the past have done for CS(i)R processes [13]. It should also be mentioned that the 100 concepts were categorized with a minimum of one and a maximum of seven dimensions (Table 3 ).

Table 3. Number of higher order UA.

\begin{tabular}{cccc}
\hline Number of Codified Dimensions & Number of Higher Order UA & Weighting in the Google Count (\%) & Distribution \\
\hline 7 & 2 & 0.6 & 0.3 \\
6 & 1 & 2.7 & \\
5 & 2 & 4.8 & \\
4 & 12 & 37.4 & 36.2 \\
2 & 34 & 18.1 & \\
1 & 33 & Total $=100 \%$ & \\
\hline
\end{tabular}




\subsection{Triad Model and Combination of Dimensions}

By exploring Appendix A, it may be observed that the sustainability concepts studied constitute anything from one to several categories with an associated $f_{k j}$; the volume of information generated is compiled in Table 3 . Here, the number of dimensions included in a given definition, the number of definitions that belong to it and the weighting fraction of the count performed in Google may all be inferred. Table 3 shows that, on average, just over $70 \%$ of the sustainability concepts studied in this article have been cited, using only dyads and triads, with triads having greater weighting in the Google count.

Table 4 shows the different types of triads identified in the search for each set of definitions (through a combination of dimensions resulting in $100 \mathrm{UAs}$ ), as well as their weighting fraction from $37.4 \%$ of the Google count. The results show that the association by triads of 34 units of analysis is that which carries the greatest weighting. Thus, a model of triads is defined consisting of the breakdown, with respect to the initial sample, of the 34 UAs catalogued for the corresponding study of their individual contributions (\% weighting fraction) as a triad of sustainability dynamics (Table 4).

Table 4. Triad model.

\begin{tabular}{cccc}
\hline Triad Number & Triads & Number of UA Included & Weighting Fraction (\%) \\
\hline 6 & Economic-Political-Social & 2 & 0.6 \\
11 & Economic-Social-Ethical & 8 & 6.7 \\
12 & Economic-Social- & 7 & 6.7 \\
13 & Environmental & 1 & 0.1 \\
15 & Economic-Cultural-Ethical & 4 & 6.2 \\
27 & Economic-Ethical- & Environmental & 4 \\
32 & Political-Social-Ethical & 1 & 44.6 \\
33 & Social-Cultural-Ethical & 1 & 0.2 \\
34 & Social-Cultural- & 6 & 0.5 \\
& Environmental & Total $=34$ & 34.4 \\
\hline
\end{tabular}

The data obtained from Table 4 suggest that sustainability processes are vectorized by a political, social and ethical category, while the dimensions that are weakly defined are the economic (for example, triads 6 and 13, with $0.6 \%$ and $1 \%$ ) and the cultural (for example, triads 13 and 32 and 33, with $0.1 \%, 0.2 \%$ and $0.5 \%$ ), while the legal category does not figure at all.

If we apply combinatorial analysis, the grouping of seven elements by threes provides 35 possible triads, such as those shown in Table 5. Of these, only nine have been shown in the study, excluding the remaining 26. This information was collected by taking the individual contribution of each dimension or $\% P D_{j}$ and taking the algebraic sum of the triad to obtain its relative importance, in decreasing order (Table 5).

At the top of the table, labelled "appearing", the data are essentially the same as those already obtained in Table 4 and do not provide additional information, except by the order of their relevance score. The interval of relative importance $21,8,31,28,4,29,18,35,25,10$, 2, 26 and 16 may be defined in which those triads not featuring in the categorization had an equal probability of having done so.

The objective is to try to demonstrate whether, in the existing sustainability processes contemplated by experts, there are one or more dimensions in addition to the established triad 11. To achieve this, the entire contribution of the economic, legal and successive dimensions was summed, as shown in Table 6. This shows the most representative dimensions in both sections since, within the "not appearing" group, they represent a mirrored value or reflection of their greater contribution to sustainability; in addition, within this range, the legal category appears as a "lost" dimension within the current processes of sus- 
tainability. Table 6 also shows that the cultural category vectorizes sustainability processes only residually.

Table 5. Relative importance.

\begin{tabular}{|c|c|c|c|c|c|c|c|c|c|}
\hline & Triad & Economic & Legal & Political & Social & Cultural & Ethical & Environmental & $\begin{array}{c}\text { Relative } \\
\text { Importance }(0 / 1)\end{array}$ \\
\hline \multirow{9}{*}{ 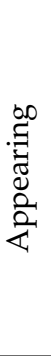 } & 11 & 0.31 & & & 0.72 & & 0.80 & & 1.83 \\
\hline & 27 & & & 0.26 & 0.72 & & 0.80 & & 1.78 \\
\hline & 34 & & & & 0.72 & & 0.80 & 0.25 & 1.77 \\
\hline & 32 & & & & 0.72 & 0.04 & 0.80 & & 1.56 \\
\hline & 15 & 0.31 & & & & & 0.80 & 0.25 & 1.36 \\
\hline & 6 & 0.31 & & 0.26 & 0.72 & & & & 1.29 \\
\hline & 12 & 0.31 & & & 0.72 & & & 0.25 & 1.28 \\
\hline & 13 & 0.31 & & & & 0.04 & 0.80 & & 1.15 \\
\hline & 33 & & & & 0.72 & 0.04 & & 0.25 & 1.01 \\
\hline \multirow{26}{*}{ 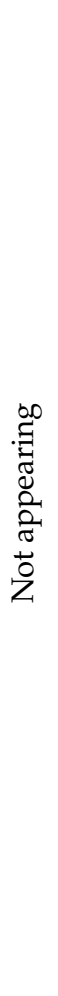 } & 21 & & 0.03 & & 0.72 & & 0.80 & & 1.55 \\
\hline & 8 & 0.31 & & 0.26 & & & 0.80 & & 1.37 \\
\hline & 31 & & & 0.26 & & & 0.80 & 0.25 & 1.31 \\
\hline & 28 & & & 0.26 & 0.72 & & & 0.25 & 1.23 \\
\hline & 4 & 0.31 & 0.03 & & & & 0.80 & & 1.14 \\
\hline & 29 & & & 0.26 & & 0.04 & 0.80 & & 1.10 \\
\hline & 18 & & 0.03 & 0.26 & & & 0.80 & & 1.09 \\
\hline & 35 & & & & & 0.04 & 0.80 & 0.25 & 1.09 \\
\hline & 25 & & 0.03 & & & & 0.80 & 0.25 & 1.08 \\
\hline & 10 & 0.31 & & & 0.72 & 0.04 & & & 1.07 \\
\hline & 2 & 0.31 & 0.03 & & 0.72 & & & & 1.06 \\
\hline & 26 & & & 0.26 & 0.72 & 0.04 & & & 1.02 \\
\hline & 16 & & 0.03 & 0.26 & 0.72 & & & & 1.01 \\
\hline & 22 & & 0.03 & & 0.72 & & & 0.25 & 1.00 \\
\hline & 23 & & 0.03 & & & 0.04 & 0.80 & & 0.87 \\
\hline & 9 & 0.31 & & 0.26 & & & & 0.25 & 0.82 \\
\hline & 20 & & 0.03 & & 0.72 & 0.04 & & & 0.79 \\
\hline & 14 & 0.31 & & & & 0.04 & & 0.25 & 0.60 \\
\hline & 7 & 0.31 & & 0.26 & & 0.04 & & & 0.61 \\
\hline & 1 & 0.31 & 0.03 & 0.26 & & & & & 0.60 \\
\hline & 5 & 0.31 & 0.03 & & & & & 0.25 & 0.59 \\
\hline & 30 & & & 0.26 & & 0.04 & & 0.25 & 0.55 \\
\hline & 19 & & 0.03 & 0.26 & & & & 0.25 & 0.54 \\
\hline & 3 & 0.31 & 0.03 & & & 0.04 & & & 0.38 \\
\hline & 17 & & 0.03 & 0.26 & & 0.04 & & & 0.33 \\
\hline & 24 & & 0.03 & & & 0.04 & & 0.25 & 0.32 \\
\hline
\end{tabular}

Table 6. Relative importance.

\begin{tabular}{cccccccc}
\hline & Economic & Legal & Political & Social & Cultural & Ethical & Environmental \\
\hline Appearing & 1.55 & 0.00 & 0.52 & 5.04 & 0.12 & 4.80 & 1.00 \\
Not appearing & 3.10 & 0.45 & 3.38 & 5.76 & 0.48 & 7.20 & 2.75 \\
\hline
\end{tabular}

This leads to two complementary positions: on the one hand, to the induction of the current concept of sustainability as that resulting from the two most commonly used approaches within the political-social-ethical dimension and to complement it with the definition of greatest weighting, as shown in Table 7. 
Table 7. Induction.

\begin{tabular}{cccc}
\hline Holling (2001) & $\begin{array}{c}\text { Process of creating, innovating and experimenting in order to increase the } \\
\text { adaptive capacities of ecosystems and of individuals and human societies as a } \\
\text { whole, in a changing context of disturbance, uncertainty and surprise }\end{array}$ & $\begin{array}{c}\text { Political } \\
\text { Social }\end{array}$ \\
Montensen (2000, p. 29) & $\begin{array}{c}\text { Represents a new paradigm based on a model of citizenship that must be and } \\
\text { needs to be shaped and informed }\end{array} \quad \begin{array}{c}\text { Political } \\
\text { Social }\end{array}$ \\
Ethical
\end{tabular}

\section{Conclusions}

It is clear from the study that the dimensions that currently contribute most to the dynamics of sustainability processes are the political, social and ethical. Indeed, each of these dimensions makes a significant individual contribution (Table 2), and jointly their weighting fraction is $44.6 \%$ (Table 4). According to the distribution set out in Table 3 , three of the original seven categories are sufficient to establish the definition of sustainability due to their large number of UAs and weighting in the Google count.

The qualitative study carried out in this work makes it possible to conclude that the trend of current sustainability processes is to move toward environmental contributionsalbeit in the very long term due to existing weighting differences-while the legal and cultural dimensions are excluded, being implicitly residual in character.

Sustainability describes a phenomenon imbued with political interests, despite the lack of public policies that ensure its deployment and normal development, which should rather emphasize strong social commitment and defense of the principles that guide human behavior. In other words, instead of being a common and widespread commitment, it is evident that sustainability processes are used as subordinate elements of economic growth and are complicit in substantial environmental degradation. This is shown by the fact that, contrary to the a priori societal expectation, the environmental dimension is not included among the most important definitions, thereby conditioning the implementation, deployment and environmental protections offered by sustainability processes. It should be noted that if sustainability processes are not managed in a responsible manner, there is a danger of generating new adverse environmental and social impacts that may arise from the interrelationships between all dimensions that are not reflected in the concepts currently used and analyzed by experts.

At some point, the question will have to be asked how we, as active citizens, might address, critically and consciously, the social, economic and political order that determines our societies and our lifestyles.

Author Contributions: Conceptualization, A.L.G., J.Á.C.M., A.C.V.-T. and F.R.; methodology, A.L.G., J.Á.C.M., A.C.V.-T. and F.R.; software, A.L.G., J.Á.C.M., A.C.V.-T. and F.R.; validation, A.L.G., J.Á.C.M., A.C.V.-T. and F.R.; formal analysis, A.L.G., J.Á.C.M., A.C.V.-T. and F.R.; investigation, A.L.G., J.Á.C.M., A.C.V.-T. and F.R.; resources, A.L.G.; data curation, A.L.G. and J.Á.C.M.; writing-original draft preparation, A.L.G., J.Á.C.M., A.C.V.-T. and F.R.; writing-review and editing, A.L.G., J.Á.C.M., A.C.V.-T. and F.R.; visualization, A.L.G., J.Á.C.M., A.C.V.-T. and F.R.; supervision, A.L.G.; project administration, A.L.G.; funding acquisition, A.L.G. and J.Á.C.M. All authors have read and agreed to the published version of the manuscript.

Funding: Research project UTM 2021-23-45.

Institutional Review Board Statement: Not applicable.

Informed Consent Statement: Not applicable.

Data Availability Statement: Not applicable.

Conflicts of Interest: The authors declare no conflict of interest. 


\section{Appendix A}

The table set out below shows the source of the definitions of the processes of sustainability, the concepts related to each author and the dimension to which each belongs.

Table A1. Categorization of the concepts of sustainability.

\begin{tabular}{cc}
\hline Source & Concept \\
\hline $\begin{array}{c}\text { Acosta, Lovato and Buñay } \\
\text { (2018) [32] }\end{array}$ & $\begin{array}{c}\text { Process improvement and optimization of resources that } \\
\text { influence cost reduction }\end{array}$ \\
\hline Agyeman (2005) [33] & $\begin{array}{c}\text { The need to ensure a better quality of life for all, now and in the } \\
\text { future, in a fair and equitable way, while living within the limits } \\
\text { of ecosystem capacity }\end{array}$ \\
Allende, (1995) [34] & $\begin{array}{c}\text { Reflecting a policy and strategy of continuous economic and } \\
\text { social development that is not detrimental to the environment } \\
\text { or natural resources on whose quality the continuity of human } \\
\text { activity and development depends }\end{array}$
\end{tabular}

Frequer
7
774
7

Dimension

$7 \quad$ Economic

$\begin{array}{cc}\text { Economic } \\ \text { Political } \\ 774 & \text { Social }\end{array}$

Environmental Ethical

Economic

Political

Social social development that is not detrimental to the environment activity and development depends

Environmental

Cultural

Ethical

\begin{tabular}{|c|c|c|c|}
\hline $\begin{array}{l}\text { Alonso-Almeida, } \\
\text { Marimon and Llach (2015, } \\
\text { p. 140) [35] }\end{array}$ & $\begin{array}{l}\text { Meeting the needs of today's generation without sacrificing the } \\
\text { ability of future generations to meet their own needs }\end{array}$ & 61 & $\begin{array}{l}\text { Social } \\
\text { Ethical }\end{array}$ \\
\hline $\begin{array}{l}\text { Aragonés, Izurieta and } \\
\text { Raposo (2003) [36] }\end{array}$ & Discourse involving political, social and economic actors & 49 & $\begin{array}{l}\text { Economic } \\
\text { Political } \\
\text { Social }\end{array}$ \\
\hline Artaraz (2002) [37] & $\begin{array}{c}\text { Productive systems that use only renewable resources and } \\
\text { energies, and do not produce waste, since they return to nature } \\
\text { (through compost) or become an input for another } \\
\text { manufactured product }\end{array}$ & 342 & $\begin{array}{l}\text { Economic } \\
\text { Environmental } \\
\text { Ethical }\end{array}$ \\
\hline Austermühle (2012) [38] & $\begin{array}{l}\text { Having no negative impact on the global environment, society } \\
\text { or economy through environmentally friendly activities, } \\
\text { ensuring that all processes, products and operations consider } \\
\text { the environmental challenges while producing an } \\
\text { economic benefit }\end{array}$ & 39 & $\begin{array}{l}\text { Economic } \\
\quad \text { Social } \\
\text { Environmental }\end{array}$ \\
\hline Ávila (2018) [39] & $\begin{array}{l}\text { Exploiting natural resources in a way that remains within the } \\
\text { limits of regeneration and natural growth by planning the } \\
\text { exploitation of resources and specifying the effects that } \\
\text { exploitation will have on the whole ecosystem }\end{array}$ & 92 & $\begin{array}{l}\text { Economic } \\
\text { Environmental } \\
\text { Ethical }\end{array}$ \\
\hline Ayres (1996) [40] & $\begin{array}{l}\text { Argues that the concept of sustainability guides how humanity } \\
\text { must act in relation to nature and be responsible for its } \\
\text { own generations }\end{array}$ & 100 & $\begin{array}{l}\text { Environmental } \\
\text { Ethical }\end{array}$ \\
\hline Azqueta (1994) [41] & Subordination of nature conservation to economic growth & 323 & $\begin{array}{c}\text { Economic } \\
\text { Environmental }\end{array}$ \\
\hline Banco Mundial (1999) [42] & $\begin{array}{l}\text { The ability of a project to maintain an acceptable level of flow of } \\
\text { profits throughout its economic life }\end{array}$ & & $\begin{array}{l}\text { Economic } \\
\text { Legal }\end{array}$ \\
\hline Barcellos (2010) [43] & $\begin{array}{l}\text { It is an ongoing process that depends on the commitment to } \\
\text { pursuing the goals set and having strategies that generate a } \\
\text { long-term competitive advantage }\end{array}$ & 1 & Economic \\
\hline Bermejo (2008) [44] & $\begin{array}{c}\text { Ensuring that the needs of the present are met without } \\
\text { compromising the ability of future generations to meet } \\
\text { their own }\end{array}$ & 1 & $\begin{array}{l}\text { Social } \\
\text { Ethical }\end{array}$ \\
\hline BNP Paribas (2009) [45] & $\begin{array}{l}\text { Point at which the economic, social and environmental } \\
\text { demands of a business can be balanced with those of the society } \\
\text { in which it develops, thereby caring for the needs of the future }\end{array}$ & 3 & $\begin{array}{l}\text { Economic } \\
\text { Social } \\
\text { Environmental } \\
\text { Ethical }\end{array}$ \\
\hline
\end{tabular}


Table A1. Cont.

\begin{tabular}{|c|c|c|c|}
\hline Source & Concept & Frequency & Dimension \\
\hline $\begin{array}{l}\text { Boada, Rocchi and Kuhndt } \\
\text { (2005) [46] }\end{array}$ & $\begin{array}{l}\text { It refers not only to environmental aspects, but also involves } \\
\text { social responsibility and economic viability, which reflects the } \\
\text { complexity of the concept, since restricting it to the } \\
\text { environmental gives an erroneous as well as a partial or } \\
\text { incomplete perspective }\end{array}$ & 6 & $\begin{array}{l}\text { Economic } \\
\text { Social } \\
\text { Environmental } \\
\text { Ethical }\end{array}$ \\
\hline Buarque (1994) [47] & $\begin{array}{l}\text { Qualitative and quantitative process of social change that } \\
\text { balances environmental conservation and social equity over } \\
\text { time and space }\end{array}$ & 1 & $\begin{array}{l}\text { Economic } \\
\quad \text { Social } \\
\text { Environmental }\end{array}$ \\
\hline Bybee (1991, p. 151) [48] & $\begin{array}{l}\text { It is the outstanding central unifying idea at this time in human } \\
\text { history and requires the consideration of all interconnected } \\
\text { problems on a global scale }\end{array}$ & 383 & $\begin{array}{l}\text { Social } \\
\text { Ethical }\end{array}$ \\
\hline
\end{tabular}

Camacho-Ruiz,

Carrillo-Reyes,

Rioja-Paradela, and

Espinoza-Medinilla (2016) [49]

\begin{tabular}{|c|c|c|c|}
\hline Carpintero (1999) [50] & $\begin{array}{l}\text { The lasting relationship of every socioeconomic system with } \\
\text { its ecosystem }\end{array}$ & 2 & $\begin{array}{l}\text { Economic } \\
\text { Social }\end{array}$ \\
\hline Carrizosa (1998) [51] & $\begin{array}{l}\text { Inherent property of a process that perpetuates its existence } \\
\text { within a given system }\end{array}$ & 31 & Ethical \\
\hline Carvalho (1994) [52] & $\begin{array}{c}\text { Process of transformation in which the exploitation of resources, } \\
\text { the direction of investments, the orientation of technological } \\
\text { development and institutional change harmonize and reinforce } \\
\text { the present and future potential, with the aim of meeting } \\
\text { human needs and aspirations }\end{array}$ & 12 & $\begin{array}{l}\text { Economic } \\
\text { Political } \\
\text { Social }\end{array}$ \\
\hline $\begin{array}{l}\text { Cepal and Pnuma } \\
\text { (2002) [53] }\end{array}$ & $\begin{array}{l}\text { Recognition of the role of the environment and natural } \\
\text { resources in ensuring economic progress }\end{array}$ & 15 & $\begin{array}{c}\text { Economic } \\
\text { Environmental }\end{array}$ \\
\hline CNUMAD (1992) [54] & $\begin{array}{l}\text { Integration of economic, social, cultural, political and } \\
\text { ecological factors }\end{array}$ & 5 & $\begin{array}{l}\text { Economic } \\
\text { Political } \\
\text { Social } \\
\text { Environmental } \\
\text { Cultural }\end{array}$ \\
\hline $\begin{array}{l}\text { Colucci-Gray, Camino, } \\
\text { Barbiero, and Gray (2006, } \\
\text { p. 244) [55] }\end{array}$ & $\begin{array}{c}\text { A system of values that has emerged in recent years as a result } \\
\text { of a new sensitivity toward the earth and related to "ethics of } \\
\text { the planet" }\end{array}$ & 261 & $\begin{array}{l}\text { Environmental } \\
\text { Ethical }\end{array}$ \\
\hline $\begin{array}{l}\text { ConteGrand and Deliar } \\
\quad(2018, \text { p. 66) [56] }\end{array}$ & $\begin{array}{l}\text { Maximum social well-being, defined based on the values } \\
\text { of society }\end{array}$ & 17 & $\begin{array}{l}\text { Social } \\
\text { Cultural } \\
\text { Ethical }\end{array}$ \\
\hline Costanza (1997) [57] & $\begin{array}{l}\text { Viability of the complex interaction between two dynamic } \\
\text { systems, the socioeconomic and the ecosystem }\end{array}$ & 59 & $\begin{array}{l}\text { Economic } \\
\text { Social }\end{array}$ \\
\hline $\begin{array}{l}\text { Contreras and Rojas (2015, } \\
\text { p. 77) [58] }\end{array}$ & Long-term value creation & 51 & Economic \\
\hline Conway (1993, p. 380) [59] & $\begin{array}{l}\text { Ability of a system to maintain its productivity } \\
\text { despite disturbances }\end{array}$ & 220 & $\begin{array}{l}\text { Economic } \\
\text { Political }\end{array}$ \\
\hline $\begin{array}{l}\text { Cutter-Mackenzie and } \\
\text { Smith (2003) [60] }\end{array}$ & $\begin{array}{l}\text { It is not only about understanding problems, but making sense } \\
\text { of everyday experiences and doing so both in the personal and } \\
\text { social spheres and in the global framework }\end{array}$ & 261 & $\begin{array}{l}\text { Social } \\
\text { Ethical }\end{array}$ \\
\hline Daly (1990) [61] & Viability of a socioeconomic system over time & 2182 & $\begin{array}{c}\text { Economic } \\
\text { Social }\end{array}$ \\
\hline $\begin{array}{l}\text { Díaz and Camejo } \\
\text { (2015) [62] }\end{array}$ & $\begin{array}{l}\text { Viable development over time whose essential condition is that } \\
\text { the capabilities of the socioeconomic system not increase and } \\
\text { may be available for the generations to come }\end{array}$ & 217 & $\begin{array}{l}\text { Economic } \\
\text { Social } \\
\text { Ethical }\end{array}$ \\
\hline
\end{tabular}

$\begin{gathered}\text { Sustaining development while maintaining its physical and } \\ \text { vital sustenance }\end{gathered}$
$\begin{gathered}\text { Economic } \\ \text { Ethical }\end{gathered}$

conomic 
Table A1. Cont.

\begin{tabular}{|c|c|c|c|}
\hline Source & Concept & Frequency & Dimension \\
\hline $\begin{array}{l}\text { Ebel and Kissmann }(2011, \\
\text { p. 72) [63] }\end{array}$ & The needs of future and current generations & & $\begin{array}{l}\text { Social } \\
\text { Ethical }\end{array}$ \\
\hline Edwars (2005) [64] & $\begin{array}{c}\text { Diverse, multicultural, multiperspective and global revolution, } \\
\text { built around four dimensions, ecological, economic, fairness } \\
\text { and education }\end{array}$ & 14 & $\begin{array}{l}\text { Economic } \\
\text { Cultural } \\
\text { Ethical }\end{array}$ \\
\hline Ehrenfeld (2005) [65] & Possibility of allowing all forms of life to always thrive & & Ethical \\
\hline Elizalde (2004) [66] & $\begin{array}{l}\text { It is a collective task with no pre-established conditions since it } \\
\text { is a conceptual construction that requires debate and the } \\
\text { participation of all the actors involved. To achieve this will } \\
\text { demand a huge political and cultural effort of all humankind }\end{array}$ & 238 & $\begin{array}{l}\text { Political } \\
\text { Social } \\
\text { Cultural } \\
\text { Ethical }\end{array}$ \\
\hline Estévez (2013) [67] & $\begin{array}{c}\text { Addressing current needs without compromising the ability of } \\
\text { future generations to meet their own, ensuring the balance } \\
\text { between economic growth, environmental care and social } \\
\text { well-being }\end{array}$ & 70 & $\begin{array}{l}\text { Economic } \\
\text { Social } \\
\text { Environmental } \\
\text { Ethical }\end{array}$ \\
\hline $\begin{array}{l}\text { Feil and Schreiber }(2017, \mathrm{p} \\
\text { 673) [68] }\end{array}$ & $\begin{array}{l}\text { Having the worry about future existence of natural resources to } \\
\text { support the continuation of human life as its foundation }\end{array}$ & 33 & $\begin{array}{l}\text { Social } \\
\text { Environmental } \\
\text { Ethical }\end{array}$ \\
\hline $\begin{array}{l}\text { Fernández and Gutiérrez } \\
\text { (2013, p. 122) [69] }\end{array}$ & $\begin{array}{l}\text { Improving the quality of human life by living within the } \\
\text { load-bearing or sustaining capacity of supporting ecosystems }\end{array}$ & 117 & $\begin{array}{l}\text { Social } \\
\text { Environmental } \\
\text { Ethical }\end{array}$ \\
\hline Gallopín (1996, p. 105) [70] & Set of basic system attributes viewed as a whole & 323 & Ethical \\
\hline Gallopín (2003) [9] & $\begin{array}{l}\text { Attribute of systems open to interactions with the external } \\
\text { world. It is not a fixed state of constancy, but the dynamic } \\
\text { preservation of the essential identity of the system amid } \\
\text { permanent changes }\end{array}$ & 713 & $\begin{array}{l}\text { Cultural } \\
\text { Ethical }\end{array}$ \\
\hline Garcés (2000) [71] & $\begin{array}{l}\text { It is a new way of understanding the relationships between } \\
\text { people and their environment from a social perspective that } \\
\text { involves prioritizing the psychological and social satisfaction of } \\
\text { the individual and their quality of life over } \\
\text { algorithmic processes }\end{array}$ & 5 & $\begin{array}{l}\text { Political } \\
\text { Social } \\
\text { Ethical }\end{array}$ \\
\hline Gómez (2015) [72] & $\begin{array}{l}\text { It involves comparing various scenarios involving resource } \\
\text { consumption, the most sustainable being that which can be } \\
\text { made effective with the greatest efficiency and at the lowest } \\
\text { possible cost in resources }\end{array}$ & 1 & Economic \\
\hline $\begin{array}{l}\text { González, Montes, Santos, } \\
\text { and Monedero (2008) [73] }\end{array}$ & $\begin{array}{l}\text { Basic principle or premise of global sustainable development, in } \\
\text { which a society's primary objective is to meet its basic needs in } \\
\text { such a way that it can maintain, now and in the future, } \\
\text { acceptable levels of social well-being }\end{array}$ & 9 & $\begin{array}{l}\text { Social } \\
\text { Ethical }\end{array}$ \\
\hline Green Facts (2021) [74] & $\begin{array}{l}\text { A characteristic or state whereby the needs of the present and } \\
\text { local population can be met without compromising the ability } \\
\text { of future generations or populations in other locations to meet } \\
\text { their needs }\end{array}$ & 1 & $\begin{array}{l}\text { Economic } \\
\text { Social } \\
\text { Environmental } \\
\text { Ethical }\end{array}$ \\
\hline $\begin{array}{l}\text { Guzmán and Alonso } \\
\text { (2007) [75] }\end{array}$ & $\begin{array}{l}\text { Exploitation of natural resources that does not put in jeopardy } \\
\text { their availability to future generations and that leads to a sense } \\
\text { of nature as a resource of the liberal economy }\end{array}$ & 127 & $\begin{array}{l}\text { Economic } \\
\text { Social } \\
\text { Environmental }\end{array}$ \\
\hline $\begin{array}{l}\text { González and De Lázaro y } \\
\text { Torres (2005) [76] }\end{array}$ & $\begin{array}{l}\text { It is the quest for urban development that does not degrade the } \\
\text { environment and provides quality of life for citizens }\end{array}$ & 4 & $\begin{array}{l}\text { Economic } \\
\text { Political } \\
\text { Social } \\
\text { Environmental } \\
\text { Ethical }\end{array}$ \\
\hline $\begin{array}{l}\text { Hart and Milstein } \\
\text { (2003) [77] }\end{array}$ & Creating value at the level of strategies and practices & 2115 & Ethical \\
\hline
\end{tabular}


Table A1. Cont.

\begin{tabular}{|c|c|c|c|}
\hline Source & Concept & Frequency & Dimension \\
\hline Hicks (1946, p. 27) [78] & $\begin{array}{l}\text { Maximum amount of resources that a person can consume in a } \\
\text { period and still be as well off at the end of the period as s/he } \\
\text { was at the beginning }\end{array}$ & 72 & $\begin{array}{c}\text { Economic } \\
\text { Legal } \\
\text { Political } \\
\text { Social } \\
\text { Environmental } \\
\text { Cultural } \\
\text { Ethical }\end{array}$ \\
\hline Holling (2001) [79] & $\begin{array}{c}\text { Process of creating, innovating and experimenting in order to } \\
\text { increase the adaptive capacities of ecosystems and individuals } \\
\text { and human societies as a whole in a changing context of } \\
\text { disturbance, uncertainty and surprise }\end{array}$ & 4557 & $\begin{array}{l}\text { Political } \\
\text { Social } \\
\text { Ethical }\end{array}$ \\
\hline $\begin{array}{l}\text { Idrovo-Carlier, S. and } \\
\text { Torres-Castillo (2017) [80] }\end{array}$ & $\begin{array}{l}\text { It refers to the individual. Human sustainability is achieved } \\
\text { when people are able to harmonize all areas in which they } \\
\text { develop to reach their personal fulfillment without sacrificing } \\
\text { their quality of life }\end{array}$ & 1 & $\begin{array}{l}\text { Social } \\
\text { Ethical }\end{array}$ \\
\hline Jimenez (1998, p. 61) [81] & $\begin{array}{l}\text { Principle of complementarity and incompatibility between } \\
\text { growth and nature }\end{array}$ & 4 & $\begin{array}{l}\text { Economic } \\
\text { Environmental } \\
\text { Ethical }\end{array}$ \\
\hline Kammerbauer (2001) [82] & A policy objective that falls within the ethics of responsibility & 49 & $\begin{array}{l}\text { Political } \\
\text { Social } \\
\text { Ethical }\end{array}$ \\
\hline Kates et al. (2001) [83] & Is caring for the earth, its living biota and its people & 3504 & $\begin{array}{l}\text { Social } \\
\text { Environmental } \\
\text { Ethical }\end{array}$ \\
\hline $\begin{array}{l}\text { Khandker, Baqui, and } \\
\text { Zahed (1995) [84] }\end{array}$ & $\begin{array}{l}\text { The program's ability to carry out its activities and services on } \\
\text { an ongoing basis, in the quest for the fulfillment of its objectives }\end{array}$ & 556 & Ethical \\
\hline $\begin{array}{l}\text { Lalangui, Espinoza, and } \\
\text { Pérez }(2017, \text { p. 148) [85] }\end{array}$ & An integral part of social responsibility & 58 & $\begin{array}{l}\text { Social } \\
\text { Ethical }\end{array}$ \\
\hline $\begin{array}{l}\text { Langenwalter } \\
(2009, \text { p. 10) [86] }\end{array}$ & $\begin{array}{c}\text { Sustainability involves complex and changing environmental } \\
\text { dynamics that affect human livelihoods and well-being, with } \\
\text { intersecting ecological, economic and sociopolitical dimensions, } \\
\text { both globally and locally }\end{array}$ & 15 & $\begin{array}{l}\text { Economic } \\
\quad \text { Legal } \\
\text { Social } \\
\text { Environmental }\end{array}$ \\
\hline Linares (2013) [87] & $\begin{array}{l}\text { Creating value on aggregate. Individuals are sustainable when } \\
\text { they add more value than they subtract. The same is true of an } \\
\text { enterprise, a country or a specific activity }\end{array}$ & 21 & $\begin{array}{l}\text { Economic } \\
\text { Ethical }\end{array}$ \\
\hline López (2006) [88] & $\begin{array}{l}\text { Intergenerational protection of natural resources, so that future } \\
\text { generations can enjoy them in the same conditions and at the } \\
\text { same level as previous generations }\end{array}$ & 2 & $\begin{array}{c}\text { Social } \\
\text { Environmental }\end{array}$ \\
\hline $\begin{array}{l}\text { López, López and Ancona } \\
\qquad \text { (2005) [89] }\end{array}$ & $\begin{array}{l}\text { Process that harmonizes economic growth, the preservation of } \\
\text { natural resources, the reduction of environmental deterioration, } \\
\text { social equity, all in a political context operating at all levels: } \\
\text { local, regional, national and global }\end{array}$ & 100 & $\begin{array}{c}\text { Economic } \\
\text { Legal } \\
\text { Political } \\
\text { Social } \\
\text { Environmental } \\
\text { Cultural } \\
\text { Ethical }\end{array}$ \\
\hline $\begin{array}{l}\text { Lufiego and Rabadán } \\
\qquad(2000)[11]\end{array}$ & $\begin{array}{l}\text { Generic concept that is defined as the viability of a } \\
\text { socioeconomic system over time }\end{array}$ & 69 & $\begin{array}{l}\text { Economic } \\
\text { Social } \\
\text { Ethical }\end{array}$ \\
\hline Macedo (2005) [90] & $\begin{array}{l}\text { It is the development that meets the needs of the present } \\
\text { generation without compromising the ability of future } \\
\text { generations to meet their own needs }\end{array}$ & 113 & $\begin{array}{l}\text { Social } \\
\text { Ethical }\end{array}$ \\
\hline Marcén (2009) [91] & $\begin{array}{c}\text { Concept associated with the realization that the world is not as } \\
\text { broad and limitless as we had believed }\end{array}$ & 2 & Ethical \\
\hline
\end{tabular}


Table A1. Cont.

\begin{tabular}{|c|c|c|c|}
\hline Source & Concept & Frequency & Dimension \\
\hline $\begin{array}{l}\text { Meadows, Meadows, and } \\
\text { Randers (1991) [92] }\end{array}$ & $\begin{array}{l}\text { Persisting over generations and able to look to the future with } \\
\text { enough flexibility and wisdom as not to undermine physical or } \\
\text { social systems of support }\end{array}$ & 3937 & $\begin{array}{l}\text { Social } \\
\text { Ethical }\end{array}$ \\
\hline $\begin{array}{l}\text { Millán, Hidalgo, and } \\
\text { Arjona (2015) [93] }\end{array}$ & $\begin{array}{l}\text { Responsibility related to the environment, natural resources } \\
\text { and Indigenous communities in various rural areas }\end{array}$ & 58 & $\begin{array}{l}\text { Social } \\
\text { Environmental } \\
\text { Cultural }\end{array}$ \\
\hline Mitcham (1995) [94] & $\begin{array}{c}\text { Exchanging unsustainable trends and intrinsic contradictions } \\
\text { for the interaction between economic development and } \\
\text { environmental deterioration }\end{array}$ & 242 & $\begin{array}{l}\text { Economic } \\
\text { Environmental } \\
\text { Ethical }\end{array}$ \\
\hline Mokate (2001) [95] & $\begin{array}{l}\text { The ability to be maintained or sustained. An initiative is } \\
\text { sustainable if it persists over time }\end{array}$ & 391 & Ethical \\
\hline Mokate (2004) [96] & $\begin{array}{l}\text { The ability of an initiative to maintain an adequate flow of } \\
\text { resources to ensure the continuity of expected effects }\end{array}$ & 3 & Ethical \\
\hline $\begin{array}{l}\text { Montensen } \\
(2000, \text { p. 29) [97] }\end{array}$ & $\begin{array}{l}\text { Represents a new paradigm based on a model of citizenship } \\
\text { that must be and needs to be shaped and informed }\end{array}$ & 271 & $\begin{array}{l}\text { Political } \\
\text { Social } \\
\text { Ethical }\end{array}$ \\
\hline Naredo (1996, p. 133) [98] & $\begin{array}{l}\text { Viability of the relationship between a socioeconomic system } \\
\text { and an ecosystem }\end{array}$ & 333 & $\begin{array}{l}\text { Economic } \\
\text { Social } \\
\text { Environmental }\end{array}$ \\
\hline Nogales (2006) [99] & $\begin{array}{l}\text { Having as a point of reference the natural order and the use of } \\
\text { the knowledge we have acquired about natural and ecological } \\
\text { systems }\end{array}$ & 43 & $\begin{array}{l}\text { Social } \\
\text { Environmental } \\
\text { Ethical }\end{array}$ \\
\hline $\begin{array}{l}\text { O'Connor } \\
(1994, \text { p. 411) [100] }\end{array}$ & $\begin{array}{l}\text { Relationship between a socioeconomic system and an } \\
\text { ecosystem whose rate of entropy is compatible with } \\
\text { maintaining that relationship over time }\end{array}$ & 14 & $\begin{array}{l}\text { Economic } \\
\text { Social } \\
\text { Ethical }\end{array}$ \\
\hline O'Connor (2006) [101] & $\begin{array}{l}\text { Focuses on interfaces, interactions and interdependencies } \\
\text { between the economic, social and environmental spheres, with } \\
\text { the mediation of the political dimension }\end{array}$ & 220 & $\begin{array}{l}\text { Economic } \\
\text { Political } \\
\text { Social } \\
\text { Environmental }\end{array}$ \\
\hline $\begin{array}{l}\text { Organización de las } \\
\text { Naciones Unidas } \\
\quad(2018)[102]\end{array}$ & Processes of inclusion and stability & 13 & $\begin{array}{l}\text { Economic } \\
\text { Ethical }\end{array}$ \\
\hline O'Riordan (1988) [103] & $\begin{array}{l}\text { It is a phenomenon that encompasses ethical standards related } \\
\text { to the survival of all living things, the rights of future } \\
\text { generations and the institutions responsible for ensuring that } \\
\text { such rights are taken into account in policies and actions }\end{array}$ & 469 & $\begin{array}{l}\text { Legal } \\
\text { Political } \\
\text { Social } \\
\text { Ethical }\end{array}$ \\
\hline Partridge (2011) [104] & $\begin{array}{l}\text { Has many definitions, with the three most common being an } \\
\text { activity that can be continued indefinitely without causing } \\
\text { harm; doing unto others as you would have them do unto you; } \\
\text { and meeting a current generation's needs without } \\
\text { compromising those of future generations }\end{array}$ & 47 & Ethical \\
\hline Pearce (1997, p. 11) [105] & $\begin{array}{l}\text { It requires that the conditions necessary for equal access to the } \\
\text { resource base be met for the benefit of each generation }\end{array}$ & 670 & $\begin{array}{l}\text { Social } \\
\text { Ethical }\end{array}$ \\
\hline $\begin{array}{l}\text { Pearce, Albritton, Grant, } \\
\text { Steed, and Zelenika (2012, } \\
\text { p. 44) [106] }\end{array}$ & $\begin{array}{l}\text { Appropriate technology, social entrepreneurship, service } \\
\text { learning and international development to focus on what they } \\
\text { do best }\end{array}$ & 58 & $\begin{array}{l}\text { Economic } \\
\text { Social }\end{array}$ \\
\hline Pérez (2012, p. 142) [107] & $\begin{array}{l}\text { Paradigm that seeks to reconcile the conflict between the } \\
\text { production of goods and services for society (development) and } \\
\text { the environmental supply available in terms of natural } \\
\text { resources and ecosystem services }\end{array}$ & 151 & $\begin{array}{l}\text { Economic } \\
\text { Political } \\
\text { Social } \\
\text { Ethical }\end{array}$ \\
\hline Pezzey (1992) [108] & $\begin{array}{l}\text { Nondeclining utility of a representative member of society for } \\
\text { millennia into the future. }\end{array}$ & 443 & $\begin{array}{l}\text { Social } \\
\text { Ethical }\end{array}$ \\
\hline
\end{tabular}


Table A1. Cont.

\begin{tabular}{|c|c|c|c|}
\hline Source & Concept & Frequency & Dimension \\
\hline $\begin{array}{l}\text { Pezzey and Toman }(2002, \\
\text { p. 14) [109] }\end{array}$ & $\begin{array}{l}\text { Concern for intergenerational equity in the long-term decision } \\
\text { making of a society. }\end{array}$ & 186 & $\begin{array}{l}\text { Social } \\
\text { Ethical }\end{array}$ \\
\hline $\begin{array}{l}\text { Pinillos and Fernández } \\
\text { (2011) [110] }\end{array}$ & $\begin{array}{l}\text { Creating long-term value by leveraging opportunities and } \\
\text { effectively exploiting the risks inherent in economic, } \\
\text { environmental and social development }\end{array}$ & 146 & $\begin{array}{l}\text { Economic } \\
\quad \text { Social } \\
\text { Environmental }\end{array}$ \\
\hline $\begin{array}{l}\text { Plasencia, Marrero, Bajo, } \\
\text { and Nicado (2018, p. 69) } \\
\text { [111] }\end{array}$ & $\begin{array}{c}\text { Development that meets the needs of these generations without } \\
\text { compromising the ability of future generations to meet their } \\
\text { needs }\end{array}$ & 30 & $\begin{array}{l}\text { Economic } \\
\text { Social } \\
\text { Ethical }\end{array}$ \\
\hline Quiroga (2001) [112] & $\begin{array}{c}\text { Leaving to future generations a stock of natural capital equal to } \\
\text { that available to present generations, that is, sustainability is } \\
\text { seen as a process of maintaining natural capital }\end{array}$ & 332 & $\begin{array}{l}\text { Economic } \\
\text { Social } \\
\text { Ethical }\end{array}$ \\
\hline Rees (1990, p. 22) [113] & $\begin{array}{l}\text { Opportunity for a return to community values, local control } \\
\text { over resources, community-based development and other } \\
\text { forms of decentralized government }\end{array}$ & 329 & $\begin{array}{l}\text { Legal } \\
\text { Political } \\
\text { Social } \\
\text { Ethical }\end{array}$ \\
\hline Robilliard (2006) [114] & $\begin{array}{l}\text { That which, in its development, takes into account economic, } \\
\text { social and environmental aspects with a democratic attitude } \\
\text { that involves the participation of those affected by the process }\end{array}$ & 22 & $\begin{array}{l}\text { Economic } \\
\text { Social } \\
\text { Environmental }\end{array}$ \\
\hline $\begin{array}{l}\text { Rodríguez-Ariza, Frías, } \\
\text { and García }(2014, \text { p. 6) } \\
\text { [115] }\end{array}$ & $\begin{array}{l}\text { Economic, social and environmental impact of business } \\
\text { activities over a given period of time }\end{array}$ & 69 & $\begin{array}{l}\text { Economic } \\
\text { Social } \\
\text { Environmental }\end{array}$ \\
\hline $\begin{array}{l}\text { Rodríguez and Govea } \\
\text { (2006) [116] }\end{array}$ & $\begin{array}{l}\text { Anthropocentric and comprehensive concept that provides } \\
\text { well-being to present and future generations without } \\
\text { environmental-social-economic deterioration }\end{array}$ & 37 & $\begin{array}{l}\text { Economic } \\
\text { Social } \\
\text { Environmental } \\
\text { Ethical }\end{array}$ \\
\hline Rojas (2009) [117] & $\begin{array}{l}\text { Sustainability can be understood as the balance between the } \\
\text { environmental, economic and social that translates into urban } \\
\text { quality of life }\end{array}$ & 8 & $\begin{array}{l}\text { Economic } \\
\text { Social } \\
\text { Environmental } \\
\text { Ethical }\end{array}$ \\
\hline Rueda (2002) [118] & $\begin{array}{l}\text { Process of social change wherein the exploitation of resources, } \\
\text { the orientation toward technological development and } \\
\text { institutional reforms are carried out harmoniously, expanding } \\
\text { the current and future potential for the satisfaction of human } \\
\text { needs and aspirations }\end{array}$ & 8 & $\begin{array}{l}\text { Economic } \\
\text { Social } \\
\text { Ethical }\end{array}$ \\
\hline $\begin{array}{l}\text { Schreiner, Henriksen, and } \\
\text { Hansen }(2005, \text { p. 13) [119] }\end{array}$ & $\begin{array}{l}\text { Moral education on the responsibility for social action with a } \\
\text { perspective on both today and tomorrow }\end{array}$ & 173 & $\begin{array}{l}\text { Social } \\
\text { Ethical }\end{array}$ \\
\hline Toro (2007) [6] & $\begin{array}{l}\text { Maintenance of a phenomenon or dynamic process over time, } \\
\text { within margins that condition its viability. This idea of its ability } \\
\text { to last is related to its withstanding possible alterations caused } \\
\text { by external elements and/or sudden internal changes }\end{array}$ & 31 & Ethical \\
\hline $\begin{array}{l}\text { UICN, PNUMA, WWF } \\
\text { (1991) [120] }\end{array}$ & $\begin{array}{l}\text { Maintaining the load-bearing capacity of an ecosystem over the } \\
\text { course of the relationship between society and the ecosystem }\end{array}$ & 17 & $\begin{array}{l}\text { Social } \\
\text { Environmental } \\
\text { Ethical }\end{array}$ \\
\hline $\begin{array}{l}\text { Uribe, Vargas, and } \\
\text { Merchán (2018, p. 61) [121] }\end{array}$ & Permanence of results overtime & 9 & Economic \\
\hline $\begin{array}{l}\text { Vasconez and Torres }(2018, \\
\text { p. 49) [122] }\end{array}$ & $\begin{array}{l}\text { Anthropological and technocentric concept, functioning in the } \\
\text { development of productive forces and indefinite growth, which } \\
\text { puts a price on nature }\end{array}$ & 11 & $\begin{array}{c}\text { Economic } \\
\text { Environmental }\end{array}$ \\
\hline Vaitheeswaran (2002) [123] & $\begin{array}{c}\text { It is what we owe future generations and how we can reconcile } \\
\text { that with what we owe the poorest among us today }\end{array}$ & 46 & $\begin{array}{l}\text { Economic } \\
\text { Social } \\
\text { Ethical }\end{array}$ \\
\hline
\end{tabular}


Table A1. Cont.

\begin{tabular}{|c|c|c|c|}
\hline Source & Concept & Frequency & Dimension \\
\hline $\begin{array}{l}\text { Vilches and Gil } \\
\text { (2013) [124] }\end{array}$ & $\begin{array}{l}\text { It requires holistic approaches that take into account all the } \\
\text { problems that characterize the planetary emergency because } \\
\text { they are closely interconnected and mutually empowered }\end{array}$ & 59 & $\begin{array}{l}\text { Social } \\
\text { Environmental } \\
\text { Ethical }\end{array}$ \\
\hline $\begin{array}{l}\text { Vilches and Gil } \\
(2015, \text { p. 39) [125] }\end{array}$ & $\begin{array}{l}\text { Addressing the current global emergency situation and driving } \\
\text { societies' transition }\end{array}$ & 69 & $\begin{array}{l}\text { Social } \\
\text { Ethical }\end{array}$ \\
\hline Willis (2003) [126] & Communication tool, useful for dialogue between stakeholders & 1746 & Economic \\
\hline World Bank (2003) [127] & $\begin{array}{l}\text { Improve human well-being over time. The poor and the } \\
\text { vulnerable must have much greater access to assets for growth } \\
\text { to be sustainable and for the world to avoid social unrest }\end{array}$ & 20 & $\begin{array}{l}\text { Economic } \\
\text { Social } \\
\text { Ethical }\end{array}$ \\
\hline $\begin{array}{l}\text { World Commission on } \\
\text { Environment and } \\
\text { Development (1987) [128] }\end{array}$ & $\begin{array}{l}\text { Meeting the needs of the present without compromising the } \\
\text { ability of future generations to meet their own }\end{array}$ & 503 & $\begin{array}{l}\text { Economic } \\
\text { Ethical }\end{array}$ \\
\hline
\end{tabular}

\section{References}

1. Sánchez Fernández, G. Análisis De La Sostenibilidad Agraria Mediante Indicadores Sintéticos: Aplicación Empírica Para Sistemas Agrarios. Ph.D. Thesis, Universidad Politécnica de Madrid, Madrid, Spain, 16 July 2009.

2. Huisingh, D. New challenges in education for sustainable development. Clean Technol. Environ. Policy 2006, 8, 3-8. [CrossRef]

3. Ahmed, Z.; Alam, R.; Akter, S.A.; Kadir, A. Environmental sustainability assessment due to stone quarrying and crushing activities in Jaong, Sylhet. Environ. Monit. Assess. 2020, 192, 778. [CrossRef] [PubMed]

4. Cuspilici, A.; Monforte, P.; Ragusa, M.A. Study of Saharan dust inuence on PM10 measures in Sicily from 2013 to 2015. Ecol. Indic. 2017, 76, 297-303. [CrossRef]

5. Chen, W.K.; Nalluri, V.; Lin, M.L.; Lin, C.T. Identifying Decisive Socio-Political Sustainability Barriers in the Supply Chain of Banking Sector in India: Causality Analysis Using ISM and MICMAC. Mathematics 2021, 9, 240. [CrossRef]

6. Toro Sánchez, F.J. El desarrollo sostenible: Un concepto de interés para la geografía. Cuadernos Geográficos 2007, 40, 49-181. [CrossRef]

7. Ríos-Osorio, L.; Cruz-Barreiro, I.; Welsh-Rodriguez, C. The Concept of Sustainable Development from an Ecosystem Perspective: History, Evolution, and Epistemology. In Ecological Dimensions for Sustainable Socio Economic Development. Southampton; YañezArancibia, A., Dávalos-Sotelo, R., Day, J., Reyes, E., Eds.; WIT Press: Boston, MA, USA, 2013; Chapter 2; pp. $29-46$.

8. Brundtland, G.H. Informe de la Comisión Mundial Sobre Medio Ambiente y el Desarrollo: Nuestro futuro Común. Documentos de las Naciones Unidas, 416. 1987. Available online: https:/ / bit.ly/3w1GHKG (accessed on 8 February 2021).

9. Gallopín, G. Sostenibilidad y Desarrollo Sostenible: Un Enfoque Sistémico; CEPAL, Serie Medio Ambiente y Desarrollo: Santiago, Chile, 2003; pp. 1-44.

10. Salas-Zapata, W.A.; Ríos-Osorio, L.A.; Del Castillo, J.A. Bases conceptuales para una clasificación de los sistemas socioecológicos de la investigación en sostenibilidad. Rev. Lasallista Investig. 2011, 8, 136-142.

11. Lufiego García, M.; Rabadán Verfgara, J.M. La evolución del concepto de sostenibilidad y su introducción en la enseñanza. Revista de Investigación y Experiencias Didácticas 2000, 18, 473-486.

12. Luque, A.; Casado, F. Public Strategy and Eco-Social Engagement in Latin American States: An Analysis of Complex Networks Arising from Their Constitutions. Sustainability 2020, 12, 8558. [CrossRef]

13. Luque, A.; Herrero-García, N. How corporate social (ir)responsibility in the textile sector is defined, and its impact on ethical sustainability: An analysis of 133 concepts. Corp Soc. Responsib. Environ. Manag. 2019, 26, 1285-1306. [CrossRef]

14. National Environmental Policy Act. EPA United States Environmental Protection Agency. Available online: https://www.epa. gov/nepa (accessed on 2 February 2021).

15. United Nations. Perder o Desperdiciar Menos Comida Ayudará a Conservar el Medio Ambiente. Available online: https: //news.un.org/es/story/2019/10/1463751 (accessed on 14 December 2020).

16. ZWIA-Zero Waste International Alliance. Working towards a World without Waste. Available online: http://zwia.org/ (accessed on 2 February 2021).

17. Estado Plurinacional de Bolivia. Asamblea Legislativa Plurinacional. Ley 300. Ley Marco de la Madre Tierra y Desarrollo Integral para Vivir Bien. Available online: http://www.fao.org/fileadmin/user_upload/FAO-countries/Bolivia/docs/Ley_300.pdf (accessed on 4 February 2021).

18. Luque, A. Promoción del hiperconsumo textil transnacional: La moda y el exceso como leitmotiv. Chasqui. Rev. Latinoam. Comun. 2017, 134, 83-104. [CrossRef]

19. Dominish, E.; Florin, N.; Teske, S. Responsible Minerals Sourcing for Renewable Energy. In Report Prepared for Earthworks by the Institute for Sustainable Futures; University of Technology Sydney: Sydney, Australia, 2019.

20. King, S.; Boxall, N.J.; Bhatt, A.I. Australian Status and Opportunities for Lithium Battery Recycling; CSIRO: Canberra, Australia, 2018. 
21. Visser, W. Revisiting Carroll's CSR pyramid: An African Perspective. In Corporatecitizenship in Developing Countries; Pedersen, E.R., Huniche, M., Eds.; Copenhagen Business School Press: Copenhagen, Danmark, 2006; pp. $29-56$.

22. Torugsa, N.; O'Donohue, W.; Hecker, R. Proactive CSR: An empirical analysis of the role of its economic, social and environmental dimensions on the association between capabilities and performance. J. Bus. Ethics 2013, 115, 383-402. [CrossRef]

23. Ley de Economía Social/Gobierno de España. Ley 5/2011, de 29 de Marzo, de Economía Social. Available online: https: / / www.boe.es/buscar/doc.php?id=BOE-A-2011--5708 (accessed on 10 February 2021).

24. Rostow, E. Planteamiento Para la Libertad; Editorial Legal Omeba: Buenos Aires, Argentina, 1962.

25. Luque, A. Corruption in the transnational textile industry: An exception or the rule? Empresa y Humanismo 2018, 21, 123-184. [CrossRef]

26. Leguizamón, A.W. Derecho Económico; Ediciones Doctrina y Ley: Bogotá, Colombia, 2002.

27. Luque, A.; de Pablos, C. Factors that promote the lack of ethics in the production and logistics practices of transnational companies. Lan Harremanak 2016, 34, 336-370. [CrossRef]

28. Luque, A.; Guamán, A. Transnational textile outsourcing: Exceptional or standard? J. Bus. Glob. 2021, 27, 143-170. [CrossRef]

29. UNESCO. Conferencia Mundial Sobre las Politicals Culturales. Available online: http://unesdoc.unesco.org/images/0005/000 525/052505sb.pdf02/02/1982 (accessed on 2 February 2021).

30. United Nations Environment Programme. Making Peace with Nature. A Scientific Blueprint to Tackle the Climate, Biodiversity and Pollution Emergencies; United Nations Environment Programme: Nairobi, Kenya, 2021. Available online: https://bit.ly/3uVieVR (accessed on 8 February 2021).

31. Luque, A.; Jiménez-Sánchez, A. Textile sustainability processes: Success, or a new way to contaminate under a friendly paradigm. J. Incl. 2018, 6, 259-288.

32. Acosta Véliz, M.; Lovato Torres, S.; Buñay Cantos, J. La responsabilidad social corporativa y su rol en las empresas ecuatorianas. Lasallista Investig. 2018, 15, 105-117. [CrossRef]

33. Agyeman, J. Environmental Justice and Sustainable Communities; New York University Press: New York, NY, USA, 2005.

34. Allende Landa, J. Desarrollo sostenible. De lo global a lo local. Ciudad y Territorio. Estud. Territ. 1995, III, 267-281.

35. Alonso-Almeida, M.; Marimon, F.; Llach, L. Difusión de las memorias de sostenibilidad en Latinoamérica: Análisis territorial y sectorial. Estud. Gerenc. 2015, 31, 139-149. [CrossRef]

36. Aragonés, J.; Izurieta, C.; Raposo, G. Revisando el concepto de desarrollo sostenible en el discurso social. Psicothema 2003, 15, 221-226.

37. Artaraz, M. Teoría de las tres dimensiones de desarrollo sostenible. Rev. Ecosistemas 2002, 11, 1-6. [CrossRef]

38. Austermühle, S. Sostenibilidad y Ecoeficiencia en la Empresa Moderna; Universidad Peruana de Ciencias Aplicadas: Lima, Peru, 2012.

39. Ávila, P. La sustentabilidad o sostenibilidad: Un concepto poderoso para la humanidad. Tabula Rasa 2018, 28, 409-423. [CrossRef]

40. Ayres, R. Statistical measures of unsustainability. Ecol. Econ. 1996, 16, 239-255. [CrossRef]

41. Azqueta, D. Valoración Económica de la Calidad Ambiental; McGraw-Hill e Interamericana de España: Madrid, Spain, 1994.

42. Banco Mundial. Sustainability of Projects: Review of Experience in the Fertilizer Subsector; World Bank Group: Washington, DC, USA. Available online: https: / / bit.ly/3g6JhrK (accessed on 15 January 2021).

43. Barcellos, L. Modelos de Gestión Aplicados a la Sostenibilidad Empresarial; Universidad de Barcelona: Barcelona, Spain, 2010.

44. Bermejo Gómez de Segura, R. Del Desarrollo Sostenible Según Brundtland a la Sostenibilidad Como Biomimesis; Universidad del País Vasco: Bilbao, Spain, 2008.

45. BNP Paribas Real State. El Glosario de la Sostenibilidad; MediaResponsable, S.L: Barcelona, Spain, 2009.

46. Boada Ortiz, A.; Rocchi, S.; Kuhndt, M. Negocios y Sostenibilidad más Allá de la Gestión Ambiental; Politécnico Grancolombiano: Bogota, Colombia, 2005.

47. Buarque, S. Desenvolvimento Sustentável da Zona da Mata de Pernambuco; IICA/SEPLAN: Recife, Brazil, 1994.

48. Bybee, R. Planet earth in crisis. Am. Biol. Teach. 1991, 53, 146-153. [CrossRef]

49. Camacho-Ruiz, E.; Carrillo-Reyes, A.; Rioja-Paradela, T.M.; Espinoza-Medinilla, E.E. Indicadores de sostenibilidad para el ecoturismo en México: Estado actual. LiminaR 2016, XIV, 156-168. [CrossRef]

50. Carpintero, O. Entre la Economía y la Naturaleza; Fundación $1^{\circ}$ de Mayo: Madrid, Spain, 1999.

51. Carrizosa, J. Construcción de la Teoría de la Sostenibilidad. Revista Transición Convivencia y Sostenibilidad 1998, $28,27-32$.

52. Carvalho, H. A participaçao e Organizaçao Consentida Como uma das Dimensões da Cidadania; Informe Integral; IICA/SEPLAN: Brasilia, Brazil, 1994.

53. Cepal y Pnuma. La Sostenibilidad del Desarrollo en América Latina y el Caribe. Desafíos y Oportunidades; Libros de Cepal: Santiago, Chile, 2002.

54. CNUMAD. Programa 21. Conferencia de las Naciones Unidas sobre el Medio Ambiente y el Desarrollo. Rio de Janeiro. Available online: https:/ / www.un.org/spanish/esa/sustdev/agenda21/riodeclaration.htm (accessed on 18 January 2021).

55. Colucci-Gray, L.; Camino, E.; Barbiero, G.; Gray, D. From Scientific Literacy to Sustainability: An Ecological Framework for Education. Sci. Educ. 2006, 90, 227-252. [CrossRef]

56. ConteGrand, M.; Deliar, V. Desarrollo sostenible y conceptos verdes. Problemas del Desarrollo 2018, 192, 63-75. [CrossRef]

57. Constanza, R. La economía Ecológica de la Sostenibilidad: Invertir en Capital Natural. In Medio Ambiente y Desarrollo Sostenible: Más Allá del Informe Brundtland; Goodland, R., Ed.; Trota: Madrid, Spain, 1997; pp. 103-114. 
58. Contreras, O.; Rojas, I. Teletrabajo y sostenibilidad empresarial. Una reflexión desde la gerencia del talento humano en Colombia. Suma de Negocios 2015, 6, 74-83. [CrossRef]

59. Conway, G. Sustainable Development: Differing Perspectives of Ecologists and Economists. World Dev. 1993, 16, 373-384. [CrossRef]

60. Cutter-Mackenzie, A.; Smith, R. The missing paradigm in environmental education. Environ. Educ. Res. 2003, 9, 497-524. [CrossRef]

61. Daly, H. Toward some operational principles of sustainable development. Ecol. Econ. 1990, 2, 1-6. [CrossRef]

62. Díaz Geniz, A.; Camejo, M. Epistemología y Educación: Articulaciones y Convergencias; Espacio Interdisciplinario: Montevideo, Uruguay, 2015.

63. Ebel, R.; Kissmann, S. Desarrollo sostenible: La investigación en un contexto intercultural. Ra Ximhai 2011, 7, 69-79. [CrossRef]

64. Edwars, A. The Sustainability Revolution; New Society Publishers: Gabriola, BC, Canada, 2005.

65. Ehrenfeld, J. The roots of sustainability. MIT Sloan Manag. Rev. 2005, 46, 23-26.

66. Elizalde, A. Paradojas y punto de fuga para una sostenibilidad posible. Polis 2004, 9, 1-20.

67. Estévez, R. Las 10 Definiciones Ecointeligentes que Debes Conocer. Available online: https://www.ecointeligencia.com/2013/0 2/10-definiciones-sostenibilidad/ (accessed on 10 December 2020).

68. Feil, A.; Schreiber, D. Sustainability and sustainable development: Unraveling overlays and scope of their meanings. Cad. EBAPE. BR 2017, 14, 667-681. [CrossRef]

69. Fernández, L.; Gutiérrez, M. Bienestar social, económico y ambiental para las presentes y futuras generaciones. Información Tecnológica 2013, 24, 121-130. [CrossRef]

70. Gallopín, G. Branching Futures and Energy Projections. Renew. Energy Dev. 1996, 10, 101-107.

71. Garcés, J. La Nueva Sostenibilidad Social; Ariel: Barcelona, Spain, 2000.

72. Gómez Jiménez, M.L. Sostenibilidad Social y Rehabilitación de Vivienda: Especial Referencia a Andalucía; Editorial Dykinson S.L.: Madrid, Spain, 2015.

73. González, J.; Montes, C.; Santos, I.; Monedero, C. Invirtiendo en capital natural: Un marco para integrar la sostenibilidad ambiental en las Politicals de cooperación. Rev. Ecosistemas 2008, 17, 52-69.

74. Green Facts Millennium Ecosystem Assessment. Available online: https://www.greenfacts.org/glossary/pqrs/sustainability.htm (accessed on 13 January 2021).

75. Guzmán, G.I.; Alonso, A.M. La investigación participativa en agroecología: Una herramienta para el desarrollo sustentable. Ecosistemas 2007, 16, 24-36.

76. González Gonzalez, M.J.; de Lázaro y Torres, M.L. La localización de la población inmigrante en España a través del Censo de la Población del 2001. Principales características. Cuadernos Geográficos 2005, 36, 35-49. [CrossRef]

77. Hart, S.; Milstein, M. Creating sustainable value. Acad. Manag. Exec. 2003, 17, 56-69. [CrossRef]

78. Hicks, J. Value and Capital; Clarendon Paperbacks: London, UK, 1946.

79. Holling, C.S. Understanding the complexity of economic, ecological, and social systems. Ecosystems 2001, 4, 390-405. [CrossRef]

80. Idrovo-Carlier, S.; Torres-Castillo, C. El Lado Humano de la Sostenibilidad. Reflexiones Desde lo Privado y lo Público; Universidad de la Sabana, Chía: Cundinamarca, Colombia, 2017.

81. Jimenez Herrero, L.M. Indicadores de desarrollo. Tras la fórmula de la sostenibilidad. Ecosistemas 1998, $24,58-63$.

82. Kammerbauer, J. Las dimensiones de la sostenibilidad: Fundamentos ecológicos, modelos paradigmáticos y senderos. Interciencia 2001, 26, 353-359.

83. Kates, R.W.; Clark, W.C.; Corell, R.; Hall, J.M.; Jaeger, C.C.; Lowe, I.; Mccarthy, J.J.; Schellnhuber, H.J.; Bolin, B.; Dickson, N.M.; et al. Sustainability Science. Science 2001, 292, 641-642. [CrossRef]

84. Khandker, S.; Baqui, K.; Zahed, K. Performance and Sustainability; Documento de Discusión No. 306; Banco Mundial: Washington, DC, USA, 1995.

85. Lalangui, J.; Espinoza Carrión, C.R.; Pérez Espinosa, M.J. Turismo sostenible, un aporte a la responsabilidad social empresarial: Sus inicios, características y desarrollo. Universidad y Sociedad 2017, 9, 148-153.

86. Langenwalter, G.A. Planet first (incorporating sustainability in corporate strategy). Strateg. Dir. 2010, 26. [CrossRef]

87. Linares, P. El concepto marco de sostenibilidad: Variables de un futuro sostenible. In ¿Es sostenible el mundo en que vivimos?: Un enfoque interdisciplinar; Bedate, C., Ed.; Universidad Pontificia Comillas: Madrid, Spain, 2013; pp. 11-32.

88. López Astudillo, A. La ruta de la sostenibilidad. Estud. Gerenc. 1998, 69, 37-42.

89. López Ricalde, C.D.; López Hernández, E.S.; Ancona Peniche, I. Desarrollo sustentable o sostenible: Una definición conceptual. Horiz. Sanit. 2005, 4. [CrossRef]

90. Macedo, B. El Concepto de Sostenibilidad; Oficina Regional de Educación para América Latina y el Caribe UNESCO: Santiago, Chile, 2005.

91. Marcén Albero, C. El Gran Desafío: Diseñar el Papel de la Escuela en la Apuesta Colectiva por la Buena Gobernabilidad del Agua. In Agua y Sostenibilidad. Recursos, Riesgos y Remedios; Moreno González, A., López Martínez, C., Eds.; Ministerio de Educación Cultura y Deporte: Madrid, Spain, 2009; pp. 231-250.

92. Meadows, D.; Meadows, D.; Randers, J. Mas Allá de Los Límites del Crecimiento; Editorial El País Aguilar: Madrid, Spain, 1991.

93. Millán Vásquez de la Torre, M.G.; Hidalgo, L.A.; Arjona Fuentes, J.M. El oleoturismo: Una alternativa para preservar los paisajes del olivar y promover el desarrollo rural y regional de Andalucía (España). Geografía Norte Grande 2015, 60, 195-214. [CrossRef] 
94. Mitcham, C. The concept of sustainable development: Its origins and ambivalence. Technol. Soc. 1995, 17, 311-326. [CrossRef]

95. Mokate, K.M. Eficacia, Eficiencia, Equidad y Sostenibilidad: ¿Qué Queremos Decir? Banco Interamericano de Desarrollo: Washington, DC, USA, 2001.

96. Mokate, K.M. Evaluación Financiera de Proyectos de Inversión, 2nd ed.; Alfaomega: Madrid, Spain, 2004.

97. Montensen, L.L. Teacher Education for Sustainability. I Global Change Education: The Scientific Foundation for Sustainability. J. Sci. Educ. Technol. 2000, 9, 27-36. [CrossRef]

98. Naredo, J.M. Sobre el origen, el uso y el contenido del término sostenible. Cuadernos de Investigación Urbanística 1996, 41, 7-18.

99. Nogales Naharro, M.A. Desarrollo rural y desarrollo sostenible. La sostenibilidad Ethics. CIRIEC-España Revista de Economía Pública Social y Cooperativa 2006, 55, 7-42.

100. O'Connor, M. Thermodynamique, complexité et codépendance écologique: La science de la joie et du deuil. Revue Internationale de Systémique 1994, 8, 397-423.

101. O'Connor, M. The "four spheres" framework for sustainability. Ecol. Complex. 2006, 3, 285-292. [CrossRef]

102. Organización de las Naciones Unidas. Informe de Los Objetivos de Desarrollo Sostenible 2018; Organización de las Naciones Unidas: New York, NY, USA, 2018.

103. O'Riordan, T. The Politics of Sustainability. In Sustainable Environmental Management; Turner, R.K., Ed.; Westview Press: Boulder, CO, USA, 1988; pp. 29-50.

104. Partridge, D.J. Activist capitalism and supply-chain citizenship: Producing ethical regimes and ready-to-wear clothes. Curr. Anthropol. 2011, 52, 97-111. [CrossRef]

105. Pearce, D. Foundations of an Ecological Economics. Ecol. Model. 1987, 38, 9-18. [CrossRef]

106. Pearce, J.; Albritton, S.; Grant, G.; Steed, G.; Zelenika, I. A new model for enabling innovation in appropriate technology for sustainable development. Sustain. Sci. Pract. Policy 2012, 8, 42-53. [CrossRef]

107. Pérez Rincón, M.A. Conceptualización sobre el Desarrollo Sostenible: Operacionalización del concepto para Colombia. Punto de Vista 2012, III, 139-158. [CrossRef]

108. Pezzey, J. Sustainability: An Interdisciplinary Guide; Environmental Values; White Horse Press: Cambridge, UK, 1992; Volume 1, pp. 321-362. [CrossRef]

109. Pezzey, J.; Toman, M. The Economics of Sustainability. Rev. J. Artic. 2002, 2, 13-17. [CrossRef]

110. Pinillos, A.A.; Fernández Fernandez, J.L. De la RSC a la sostenibilidad corporativa: Una evolución necesaria para la creación de valor. Bus. Rev. 2011, 207, 5-21.

111. Plasencia Soler, J.A.; Marrero Delgado, F.; Bajo Sanjuán, A.M.; Nicado garcía, M. Modelos para evaluar la sostenibilidad de las organizaciones. Estud. Gerenc. 2018, 34, 63-73. [CrossRef]

112. Quiroga, R. Indicadores de Sostenibilidad Ambiental y de Desarrollo Sostenible: Estado del Arte y Perspectivas; Naciones Unidas: Santiago, Chile, 2001.

113. Rees, W.E. The ecology of sustainable development. Ecologist 1990, 20, 18-23.

114. Robilliard, P. Los Ejes Centrales Para el Desarrollo de una Minería Sostenible; CEPAL: Santiago, Chile, 2006.

115. Rodríguez-Ariza, L.; Frías Aceituno, J.V.; García Rubio, R. El consejo de administración y las memorias de sostenibilidad. Revista de Contabilidad 2014, 17, 5-16. [CrossRef]

116. Rodríguez, I.; Govea, H. El discurso del desarrollo sustentable en América Latina. Revista Venezolana de Economía y Ciencias sociales 2006, 12, 37-63.

117. Rojas, C.A.; Diaz, M.A.; Jaque Castillo, E. Sostenibilidad urbana. Tome: Una propuesta para evaluar los planes reguladores chilenos. Urbano 2009, 11, 26-35.

118. Rueda, G. Desarrollo alternativo y contabilidad pública: Hacia una línea de investigación. Nómadas 2002, 16, 195-203.

119. Schreiner, C.; Henriksen, E.K.; Kirkeby Hansen, P.J. Climate Education: Empowerin today's youth to meet tomorrow 's challenges. Stud. Sci. Educ. 2005, 41, 3-50. [CrossRef]

120. UICN; PNUMA; WWF. Cuidar la Tierra. In Estrategia Para el Futuro de la Vida; Hearthscan Edition: Gland, Switzerland, 1991.

121. Uribe Macías, M.E.; Vargas Moreno, O.A.; Merchán-Paredes, L. La responsabilidad social empresarial y la sostenibilidad, criterios habilitantes en gerencia de proyectos. Entramado 2018, 14, 52-63. [CrossRef]

122. Vásconez Carrasco, M.; Torres León, L. Minería en el Ecuador: Sostenibilidad y Licitud. Estudios del Desarrollo Social Cuba y América Latina 2018, 6, 48-50.

123. Vaitheeswaran, V. The great race. Economics 2002, 364, 3-5.

124. Vilches, A.; Gil Pérez, D. Ciencia de la sostenibilidad: Un nuevo campo de conocimientos al que la química y la educación química están contribuyendo. Educación Química 2013, 24, 199-206. [CrossRef]

125. Vilches, A.; Gil Pérez, D. Ciencia de la sostenibilidad: ¿Una nueva disciplina o un nuevo enfoque para todas las disciplinas? Revista Iberoamericana de Educación 2015, 69, 39-60. [CrossRef]

126. Willis, A. The role of the global reporting initiative's sustainability reporting guidelines in the social sustainability reporting guidelines in the social screening investments. J. Bus. Ethics 2003, 43, 233-237. [CrossRef]

127. World Bank. Sustainable Development in a Dynamic World: Transforming Institutions, Growth and the Quality of Life; Oxford University Press: New York, NY, USA, 2003.

128. World Commission on Environment and Development. Report of the World Commission on Environment and Development: Our Common Future; United Nations: New York, NY, USA, 1987. 